\title{
Profile of Some Trace Elements in Selected Traditional Medicines used for Various Aliments in Ebonyi State, Nigeria
}

\author{
Ikeagwulonu Richard Chinaza ${ }^{1,6}$, Nkereuwem Sunday Etukudoh ${ }^{2}$, Ejinaka Obiora Reginald ${ }^{3}$, \\ Ibanga Imoh Etim", Obeta Mark Uchejeso ${ }^{4 *}$, Uro-Chukwu Henry Chukwuemeka ${ }^{5}$ and Odeh \\ Elizabeth Chibuzor ${ }^{6}$
}

${ }^{1}$ Department of Medical Laboratory Science, College of Health Sciences, Nnamdi Azikiwe University, Nigeria

${ }^{2}$ Department of Haematology, Federal School of Medical Laboratory Science, Jos-Nigeria

${ }^{3}$ Department of Parasitology, Federal School of Medical Laboratory Science, Jos-Nigeria

${ }^{4}$ Department of Chemical Pathology, Federal School of Medical Laboratory Science, Jos-Nigeria

${ }^{5}$ Department of Community Medicine, College of Health Science, Ebonyi State University, Nigeria

${ }^{6}$ Department of Medical Laboratory Science, Alex Ekwueme Federal University Teaching Hospital, Nigeria

*Corresponding author: Obeta Mark Uchejeso, Department of Chemical Pathology, Federal School of Medical Laboratory Science, Jos, Plateau State, Nigeria.

To Cite This Article: Ikeagwulonu Richard C, Nkereuwem Sunday E, Ejinaka Obiora R, Ibanga Imoh E, Obeta Mark U, et al., Profile of Some Trace Elements in Selected Traditional Medicines used for Various Aliments in Ebonyi State, Nigeria. 2020 - 9(3). AJBSR.MS.ID.001396. DOI: 10.34297/ AJBSR.2020.09.001396.

Received: 盋: June 03, 2020; Published: 監 July 01, 2020

\begin{abstract}
Background: Traditional medicines have been in use before conventional drugs in Nigeria and Ebonyi State in particular. The use has been on the increase of recent no matter the levels of education and exposure due to the efficacy. They are sometimes considered as dietary supplements once they are found to be rich in one or more elements. The knowledge on concentrations of these trace elements is important for determining the effectiveness of the plants in treating various ailments so as to understand their pharmacological actions.
\end{abstract}

Aim of Study: This study was conducted to investigate the profile of certain trace elements having therapeutic properties related to various ailments as found in herbal medicines sold in Ebonyi State.

Study volunteers and Methods: The herbal medications were found in various locations in Ebonyi State, Nigeria where they were displayed for sale. The mineral elements in 20 herbal medications under study such as metal ions copper, zinc and manganese were determined using atomic absorption spectrophotometer of the AA220FS Buck scientific model, air - acetylene flame at a flame temperature of $2600^{\circ} \mathrm{C}$ and flame height of $6 \mathrm{~mm}$ at varying wavelengths of each metal ions - $\mathrm{Cu}(324.8 \mathrm{~nm}), \mathrm{Zn}(213.9 \mathrm{~nm})$, and $\mathrm{Mn}(279.5 \mathrm{~nm})$.

Results: The highest mean concentration of copper among the herbal medications studied was found in African Iba (5.64 $\pm 4.19 \mathrm{mg} / \mathrm{L})$, followed by Restorative tonic $(5.26 \pm 3.78 \mathrm{mg} / \mathrm{L})$. The least concentration of copper was found in Golden seed $(0.38 \pm 0.54 \mathrm{mg} / \mathrm{L})$. For zinc, the highest concentration of zinc was found in Divine roots $(101.64 \pm 3.73 \mathrm{mg} / \mathrm{L})$, followed by Zaram pile $(96.68 \pm 5.59 \mathrm{mg} / \mathrm{L})$ and least in Deep roots $(31.54 \pm 4.04 \mathrm{mg} / \mathrm{L})$. Manganese was found to be highest in Ukwara $(17.61 \pm 5.39 \mathrm{mg} / \mathrm{L})$, followed by Golden seed $(16.45 \pm 5.87 \mathrm{mg} / \mathrm{L})$ and least in Bitter Extra $(1.43 \pm 0.42 \mathrm{mg} / \mathrm{L})$.

Conclusions: It was observed that all the medications studied had zinc, manganese and copper. Trace elements were found to be present in all the herbal medications studied and in amounts sufficient to meet the required daily allowance (RDA). The average concentrations of Cu and Mn were below the tolerable upper intake levels while that of Zinc were seen above this level.

Keywords: Traditional medicines, Trace elements, Copper, Zinc, Manganese, Nigeria 


\section{Introduction}

Medicinal plants are widely used all over the world and, according to the World Health Organization (WHO), for many millions of people, traditional medicines, including herbal medicines, are the main source of health care and, sometimes, the only source of care [1]. Their demand is growing worldwide both in developing and industrialized countries, as a complementary way to treat and to prevent diseases [2-4]. Medicinal plants play an important role in traditional medicine and are widely consumed as home remedies [5]. Thus, it can safely be presumed that a major part of traditional therapy involves the use of plant extracts or their active principles [6]. The past decade has seen a significant increase in the use of herbal medicine due to their minimal side effects, availability and acceptability to the majority of the populace especially in third world countries. Consumption of these plants contributes to the intake of minerals, essential and non essential by the people including infants and the elderly [7]. Many metabolic disorders resulting in human ailments have experimentally been shown to be managed by traditionally used medicinal plants. Among the factors attributing to the healing potential of these medicinal plants, are the trace elements present in them [8]. However, it is widely known that in higher concentration, trace elements in medicinal plants are responsible for their toxicity. Besides being used for the treatment of diseases, these traditional medicinal medications are also used as dietary supplements once they are found to be rich in one or more elements (Table 1). Elemental content in medicinal plants can vary in a wide range, depending on factors such as soil geochemical characteristics, atmospheric deposition and the ability of each plant species to selectively accumulate some of them $[9,10]$. The determination of major, minor and trace elements in medicinal plants and their impacts on human health are also of great importance due to the growth of environmental pollution that directly affects the plants and, therefore, their phytotherapics. Besides, being essential in the living system, the elements can be at the same time toxic, when at concentrations beyond those necessary for metabolic functions [11-13]. In the present study, elemental analysis of some selected traditional medicinal medication was carried out using atomic absorption spectroscopy.

\section{Materials and Methods}

\section{Study area and Population}

Ebonyi state is one of the 36 states of the Federal Republic of Nigeria located in the south eastern part of the country. Ebonyi State was carved out from the old Abia and Enugu State in October 1, 1996 with its capital as Abakaliki. It occupies a land mass of 5,935 square kilometers and is situated between latitudes 5040' and

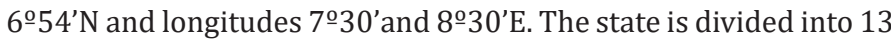
Local Government Areas (LGAs) grouped into three senatorial zones namely, Ebonyi North comprising Abakaliki, Ebonyi, Ohaukwu and Izzi LGAs; Ebonyi central made up of Ishielu, Ikwo, Ezza North and Ezza south LGAs; and Ebonyi South made up of Afikpo North, Afikpo South, Ivo, Ohaozara and Onicha LGAs (ESSHDP, 2009). Ebonyi state has one tertiary and many secondary and primary health institutions spread across the state which can either be public, private, mission or owned by nonprofit nongovernmental organization. The tertiary health institution is Alex Ekwueme University Federal Teaching Hospital in the Abakaliki capital city. The study was conducted in 6 out of these 13 local government areas of Ebonyi State. They are; Abakaliki, Ikwo, Afikpo North, Ohaukwu, Ezza North and Ebonyi Local Government Areas (LGAs). Each of the LGAs has one or more local markets where goods like Herbal medications are sold in the open market, in the bus, car and shops.

\section{Sample collection}

Three samples were collected each for twenty (20) different herbal medications shown in Table 1 The sixty (60) herbal medications were made for in-vitro administration and were purchased from various locations in Ebonyi State. The samples in liquid formulation were contained in plastic or bottle containers and contained such information like herbal product name, manufacturers name and address, production and expiration dates, NAFDAC enlisting and batch numbers. All herbal medications studied were produced and processed in Nigeria. Parameters analyzed were zinc, copper and manganese.

Table 1: Trade name of herbal medications sold in various local government of Ebonyi State, Nigeria.

\begin{tabular}{|c|c|c|c|}
\hline Trade name & Action of medications & $\begin{array}{c}\text { Locations in L.G of Ebonyi state } \\
\text { of Nigeria }\end{array}$ & $\begin{array}{c}\text { Frequency of Sale } \\
\text { percentage }(\%) \text { per week }\end{array}$ \\
\hline Goko mixture & Anti-oxidant Immune booster & Abakaliki & $\geq 50$ \\
\hline Goodwills & Treats Infections & Abakaliki & $\geq 50$ \\
\hline Dunamis & Treats Infections & Afikpo North & $\geq 50$ \\
\hline Divine roots & Immune Booster & Afikpo North & $<50$ \\
\hline Bitter extra & Anti-Oxidant & Ikwo & $<50$ \\
\hline Zaram pile & Treats Infections & Abakaliki & $\geq 50$ \\
\hline Deep roots & Male infertility & Abakaliki & $\geq 50$ \\
\hline Blood purifier & Treats infections & Abakaliki & $\geq 50$ \\
\hline Ezinne herbal & Enhance female fertility & Afikpo North & $<50$ \\
\hline
\end{tabular}




\begin{tabular}{|c|c|c|c|}
\hline Cordel silver & Treats infections & Afikpo North & $\geq 50$ \\
\hline Iketo & Treats infections & Ohaukwu & $<50$ \\
\hline African iba & A purgative and anti infectious agent & Ezza North & $\geq 50$ \\
\hline Restorative tonic & Male fertility & Ebonyi & $\geq 50$ \\
\hline Akwasa & Immune booster & Afikpo North & $\geq 50$ \\
\hline Chindus & Anti infectious agent (prostate and urinary) & Afikpo North & $<50$ \\
\hline Ukwara & Anti infectious agent & Afikpo North & $<50$ \\
\hline Asheitu adams & Enhance fertility & Ohaukwu & $<50$ \\
\hline Elcocyn-Ds & Treats Pregnancy Related Issues & Ohaukwu & $<50$ \\
\hline Golden seed & Anti Infectious Agent & Ebonyi & Abakaliki \\
\hline Katoka & Anti Infectious Agent & & $<50$ \\
\hline
\end{tabular}

\section{Sampling procedure / technique}

A questionnaire was designed to ascertain the total number of herbal medications (liquid herbal formulations) sold in Ebonyi State and provide such information like the name of the herbal product, manufacturers name and address, production and expiration dates, NAFDAC enlisting and batch numbers, function of the herbal product, frequency of sales, site of sale, name of vendor and contact address, local government under cover, village and market name and visiting date. A total of 44 herbal medications were sighted in all at the end of the survey which lasted from $1^{\text {st }}$ to $26^{\text {th }}$ June 2016 and the location of sales ranged from big stores/ shops, chemist shops, buses, cars and vendors (table and hand to hand sellers) in open markets. 21 out of the 44 medications had frequencies of fifty percent sales and below while 22 medications were above fifty percent. One medication was inconclusive and was dropped. Simple random sampling without replacement technique was used to select a total of 20 herbal medications (10 from those below $50 \%$ and 10 from above $50 \%$ of sales) used for this study. One sample (Katoka) could not be digested thus 19 different herbal medications were finally utilized for the study. The herbal samples were purchased directly from dealers/or hawkers from $2^{\text {nd }}$ to $18^{\text {th }}$ September, 2018.

\section{Trace elements determination by AAS as described by Vogel [14]}

The metal ions copper, zinc and manganese were determined using atomic absorption spectrophotometer of the AA220FS Buck scientific model, air - acetylene flame at a flame temperature of $2600^{\circ} \mathrm{C}$ and flame height of $6 \mathrm{~mm}$. The wavelength of each lamp disc at which reading was taken for each metal ions were $\mathrm{Cu}(324.8 \mathrm{~nm})$, Zn (213.9nm), Mn (279.5nm).

\section{Principle}

Metal atoms absorb strongly at discrete characteristic wavelengths (324.8nm for copper, $213.9 \mathrm{~nm}$ for zinc and $279.5 \mathrm{~nm}$ for manganese) which coincide with their emission spectra. A solution of the sample is converted into an aerosol which is injected into a flame which then converts the sample into an atomic and molecular vapor. The atomic vapor absorbs radiation from a hollow cathode lamb at specific wavelengths. This beam then traverses the flame and is focused on the entrance slit of a mono chromator, which is set to read the intensity of the chosen spectral line. Light with this wavelength is absorbed by the metal in the flame and the degree of absorption is a function of the concentration of the metal in the sample.

\section{Sample preparation and digestion using wet digestion technique}

The bottle or container containing the liquid sample was first shaken to obtain homogeneity. The digestor was then switched on and allowed to heat up to set temperature of 350 degree Celsius. $10 \mathrm{ml}$ of liquid sample was measured into a digestion tube whereas $20 \mathrm{ml}$ of nitric acid and sulphuric acid was added to the sample in the tube in the ratio $2: 1$. The tubes were then placed in the digestion block already at 350 degree Celsius and the digestion process allowed for $20 \mathrm{~min}$. The digest was then allowed to cool and later transferred into a measuring cylinder. This is followed by dilution of the digest with distilled water to a set volume of $25 \mathrm{ml}$ with the prepared digests taken to Atomic Absorption Spectrophotometer (AAS) for trace element determination.

\section{Procedure for analysis}

The proper hollow cathode lamp for the analysis was first chosen and the lamp was allowed to warm up for a minimum of 15 minutes. During this period, the instrument was aligned, and the monochromator was positioned at the correct wavelength. The proper monochromator slit width was selected, and the hollow cathode current adjusted according to the manufacturer's recommendation. The flame was subsequently lighted and the flow of fuel and oxidant regulated, the burner and nebulizer flow rate was adjusted for maximum percent absorption and stability, and the photometer was balanced. A series of standards of the element under analysis was run and a calibration curve constructed by plotting the concentrations of the standards against the absorbance. The curve corrector was set to read out the proper concentration. The samples were then aspirated and the concentrations determined directly from the readout system of the instrument. The actual concentration of the element was then mathematically derived from the formula shown below: 


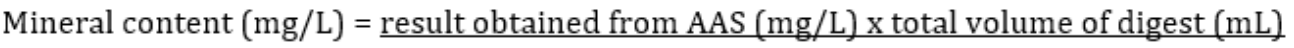

Volume of sample digested (mL)

Results

Table 2 \& 3

Table 2: Concentration of trace elements in commonly sold herbal medications in Ebonyi.

\begin{tabular}{|c|c|c|c|}
\hline Herbal Medications & Zn (mg/L) & $\mathrm{Cu}(\mathrm{mg} / \mathrm{L})$ & Mn (mg/L) \\
\hline Goko mixture & $60.27 \pm 7.12$ & $2.36 \pm 0.23$ & $2.09 \pm 0.25$ \\
\hline Goodwills & $55.78 \pm 3.03$ & $2.44 \pm 0.34$ & $1.56 \pm 0.08$ \\
\hline Dunamis & $79.24 \pm 11.43$ & $2.62 \pm 0.08$ & $7.15 \pm 1.50$ \\
\hline Divine roots & $101.64 \pm 3.73$ & $1.42 \pm 2.01$ & $6.82 \pm 0.35$ \\
\hline Bitter extra & $58.84 \pm 14.88$ & $3.20 \pm 1.30$ & $1.43 \pm 0.42$ \\
\hline Zaram pile & $96.68 \pm 5.59$ & $1.66 \pm 2.35$ & $1.72 \pm 0.71$ \\
\hline Deep roots & $31.54 \pm 4.04$ & $3.90 \pm 1.95$ & $6.91 \pm 1.40$ \\
\hline Blood purifier & $66.92 \pm 5.29$ & $66.92 \pm 5.29$ & $1.53 \pm 0.52$ \\
\hline Ezinne herbal & $67.06 \pm 17.62$ & $2.38 \pm 1.27$ & $2.09 \pm 0.40$ \\
\hline Cordel silver & $68.46 \pm 11.34$ & $3.82 \pm 1.27$ & $1.48 \pm 0.33$ \\
\hline Iketo & $65.86 \pm 0.20$ & $3.73 \pm 4.97$ & $8.50 \pm 5.75$ \\
\hline African iba & $67.02 \pm 9.78$ & $5.64 \pm 4.19$ & $6.42 \pm 3.76$ \\
\hline Restorative tonic & $62.98 \pm 3.15$ & $5.26 \pm 3.78$ & $1.44 \pm 0.16$ \\
\hline Akwasa & $67.72 \pm 4.30$ & $3.44 \pm 0.15$ & $9.21 \pm 4.94$ \\
\hline Chindus & $47.50 \pm 1.95$ & $2.14 \pm 1.30$ & $4.73 \pm 0.32$ \\
\hline Ukwara & $75.74 \pm 26.90$ & $4.82 \pm 1.78$ & $17.61 \pm 5.39$ \\
\hline Asheitu adams & $54.54 \pm 9.14$ & $5.12 \pm 0.79$ & $8.30 \pm 1.86$ \\
\hline Elcocyn-Ds & $67.58 \pm 15.53$ & $2.30 \pm 0.71$ & $3.14 \pm 1.44$ \\
\hline Golden seed & $78.98 \pm 10.83$ & $0.38 \pm 0.54$ & $16.45 \pm 5.87$ \\
\hline
\end{tabular}

Table 3: Frequency and concentration data of the trace elements in herbal medications from Ebonyi State.

\begin{tabular}{|c|c|c|c|c|}
\hline Trace element & Examined samples & $\begin{array}{c}\text { Frequency of positive } \\
\text { samples }\end{array}$ & $\begin{array}{c}\text { Concentration (mg/L) in } \\
\text { herbal medications }\end{array}$ & Reference Range(mg) \\
\hline Copper & 57 & $54(94.74 \%)$ & $3.57 \pm 0.12$ & $2.20-8.60$ \\
\hline Zinc & 57 & $57(100 \%)$ & $68.00 \pm 4.34$ & $30.7-133.16$ \\
\hline Manganese & 57 & $57(100 \%)$ & $5.96 \pm 1.42$ & $1.13-27.67$ \\
\hline
\end{tabular}

\section{Discussion}

Table 2 shows the mean level of mineral elements in herbal medications found in various locations in Ebonyi state, Nigeria. Table 3 shows the frequency and concentration data of the trace elements in the herbal medications. It was observed that all the medications studied had zinc, manganese and copper (100\% incidence rate). The mean level of $\mathrm{Cu}$ in all samples was $3.57 \pm 0.12 \mathrm{mg} / \mathrm{L}$ (Table 3 ) which is lower than its recommended tolerable upper intake levels $(10 \mathrm{mg} /$ day) and consumption of the herbal medications will not pose an immediate health risk. The mean range of $\mathrm{Cu}$ is $2.20 \mathrm{mg} / \mathrm{L}-8.60 \mathrm{mg} / \mathrm{L}$ and the highest concentration of copper among the herbal medications studied was found in African Iba $(5.64 \pm 4.19 \mathrm{mg} / \mathrm{L})$; this was followed by Restorative tonic $(5.26 \pm 3.78 \mathrm{mg} / \mathrm{L})$. The least concentration of copper was found in Golden seed $(0.38 \pm 0.54 \mathrm{mg} / \mathrm{L})$ (Table 2). For manganese, the mean level of $\mathrm{Mn}$ in all samples was $5.96 \pm 1.42 \mathrm{mg} / \mathrm{L}$ (Table 2) which is lower than its tolerable upper intake levels (11mg/day), and with 17 samples (89.5\%) having concentrations below the allowable levels, consumption of the herbal medications will not pose an immediate health risk. The mean concentration of manganese in the samples ranged $1.13 \mathrm{mg} / \mathrm{L}-27.67 \mathrm{mg} / \mathrm{L}$. Manganese was found to be highest in Ukwara $(17.61 \pm 5.39 \mathrm{mg} / \mathrm{L})$, followed by Golden seed $(16.45 \pm 5.87 \mathrm{mg} / \mathrm{L})$ and least in Bitter Extra (1.43 $\pm 0.42 \mathrm{mg} / \mathrm{L})$ (Table 2). For Zinc, the mean level of $\mathrm{Zn}$ in all samples was $68.00 \pm 4.34$ (Table 2) which is higher than its tolerable upper intake levels (40mg/day), 18 samples (94.7\%) of the herbal medications contain zinc in concentrations higher than the allowable level, and as a result, consumption of the herbal medications will pose an immediate health risk. The mean range of 
$\mathrm{Zn}$ in the samples ranged $30.7 \mathrm{mg} / \mathrm{L}-133.16 \mathrm{mg} / \mathrm{L}$ with the highest concentration of zinc found in Divine roots $(101.64 \pm 3.73 \mathrm{mg} / \mathrm{L})$, followed by Zaram pile $(96.68 \pm 5.59 \mathrm{mg} / \mathrm{L})$ and least in Deep roots (31.54 $\pm 4.04 \mathrm{mg} / \mathrm{L})$ (Table 2).

The copper level in this study is similar to one done by Saeed et al. [15], who studied heavy metal content of twenty five branded Pakistani herbal products and reported concentration range of $0.1-18 \mathrm{mg} / \mathrm{L}$. Maffo et al. [16] reported high incidence of zinc in concentrations above the permissible limit. The concentrations of copper, manganese and zinc in this study are higher than that reported by Umar et al. [17] and Moses et al. [18]. Anim et al. [19] also, reported lower copper and zinc values in the herbal medications they studied. Nwachukwu et al. [20] who assessed heavy metals content of some plant based medicines in parts of Southern Nigeria also reported Zn concentrations below the maximum permissible limit. WHO/FAO have not established a regulatory limits for copper in herbal medications, but China and Singapore set the permissible limits of $20 \mathrm{ppm}$ and $150 \mathrm{ppm}$ respectively $[17,18,21]$. Also, the WHO limits are not yet established for $\mathrm{Zn}$ and $\mathrm{Mn}$ in herbal medications, however, the permissible limits set by FAO/WHO (1989) in edible plants are 27.4-50mg/ $\mathrm{kg}$ and 44.6 to $339 \mathrm{mg} / \mathrm{kg}$ respectively $[17,18]$. The metals can be beneficial or harmful depending on their levels in the body. While copper forms parts of most body enzymes regulating various body metabolism like hemoglobin synthesis, energy production and many oxidation-reduction reactions., Zinc is required for normal growth, DNA synthesis and proper thyroid function. Utensils, polluted soil and fumigants used to preserve the herbal plant from destruction have been identified as sources of copper contamination [20] Accidental contamination can occur during manufacture and when medicinal herbs are grown in polluted soil [19]. Copper toxicity may result in skin discoloration, vomiting and liver damage while zinc toxicity can result in deleterious effect on the immune system and reduced copper level in the body. Zinc deficiency can lead to growth retardation.

\section{Conclusion}

The present study revealed the three elements of $\mathrm{Zn}, \mathrm{Cu}$, and $\mathrm{Mn}$ were found in all the herbal medications. The average concentrations of $\mathrm{Cu}$ and $\mathrm{Mn}$ were below the tolerable upper intake levels while that of Zinc were seen above this level. The high $\mathrm{Zn}$ content observed in majority of the samples has the potential of posing health risks to consumers of these medications. Therefore, due to the high patronage of these herbal products by the populace, there is need for their constant monitoring by the development of routine programmes in order to safeguard their safety since unsupervised use could have cumulative effect, which in turn may lead to their toxicity.

\section{Acknowledgement}

The authors acknowledge the technical advice and encouragement provided by Professor Onyenekwe CC and Oshim Ifeanyi Onyema of the Department of Medical Laboratory Science, Faculty of Health Sciences and Technology, College of Health Sciences, Nnamdi Azikiwe University, Nnewi Campus, Anambra State and Professor Alo Moses Nnaemeka of Department of Microbiology, Alex Ekwueme Federal University, Abakaliki Nigeria during the study.

\section{Reference}

1. World Health Organization (2016) Traditional Medicine Strategy. 20142023.

2. Thomson GE. (2010) Further consideration of Asian Medicinal plants in treating common chronic disease in West. Journal Medicine Plants Resource. 4(2): 125.

3. Kalaivanan C, Chandrasekaran M, Venkatesalu V (2013) Screening of selected medicinal plants for in vitro antidermatophytic activity Journal Mycology Medicine 23(4): 247.

4. Calvo MI, Akerreta S, Cavero RY (2013) The pharmacological validation of medicinal plants used for digestive problems in Navarra, Spain. European Journal Integrated Medicine 5: 537-546.

5. Maslennikov PV, Chupakhina GN, Skrypnik LN (2014) The content of phenolic compounds in medicinal plants of a botanical garden (Kaliningrad oblast). Biology Bulletin. 41: 133-138.

6. Farnsworth NR, Akerele O, Bingel AS, Soejarto DD, Guo Z (1985) Medicinal Plants in Therapy. Bulletin WHO. 63: 965-981.

7. Ajasab AMO., Bellob MO, Ibrahimb AO, Ogunwandea IA, Olawore NO (2004) Heavy trace metals and macronutrients status in herbal plants of Nigeria. Food Chemistry. 85: 67-71.

8. Shirin K, Imad S, Shafiq S, Fatima K (2010). Determination of major and trace elements in the indigenous medicinal plant Withania somnifera and their possible correlation with therapeutic activity. Journal Saudi Chemistry Society.14: 97-100.

9. Łozak A, Sołtyk K, Ostapczuk P, Fijałek Z. (2002). Determination of Selected Trace Elements in Herbs and Their Infusions. Science Total Environment. 289: 33-40.

10. Sattar SA, Reddy BS, Rao VK, Pradeep AS, Raju GJN, et al. (2012) Journal Radioanalysed Nuclear Chemistry 294: 337.

11. Fei T, Dehong L, Fengqun Z, Junhua L, Hua (2010) Journal Radioanalysed Nuclear Chemistry 284: 507.

12. Ebrahim AM, Eltayeb MH, Khalid H, Mohamed H, Abdalla W, Grill P, Micalke B (2012) Study on selected trace elements and heavy metals in some popular medicinal plants from Sudan. Journal Nature Medicine 66: 671-679.

13. Ranđelović SS, Kostić DA, Zarubica AR, Mitić SS, Mitić MN. (2013). The correlation of metal content in medicinal plants and water their extract. Chem Industry 67(4): 585-591.

14. Vogel AI. (2000). Text Book Of Quantitative Chemical Analysis, $6^{\text {th }}$ edn, Delhi, India, pp. 612-656.

15. Saeed M, Muhammad N, Khan H, Zakiullah (2011) Assessment of Heavy Metal Content of Branded Pakistani Herbal Products. Tropical Journal of Pharmaceutical Research. 10(4): 499-506. 
16. Maffo Maffo NL, Zapfack L, Youmbi E, Dibong SD, Ntsomboh-Ntsefong G. (2016). Heavy metal concentrations in some common medicinal plants from different geographical locations in Douala, Cameroun. International Journal Current Resource Bioscience Plant Biology 3(12): 10-23.

17. Umar A, Mohammed Y, Garba S, Faruruwa MD (2016) Quantitative Determination of Heavy Metals in Some Commonly Consumed Herbal Medicines in Kano State, Nigeria. Journal of Scientific and Engineering Research 3(2): 39-46.

18. Moses AG, Erastus G, Leonard G, Henry R (2012) Profile of Heavy Metals in Selected Medicinal Plants Used foR the Treatment of Diabetes, Malaria and Pneumoniain Kisii Region, Southwest Kenya. Global Journal of Pharmacology 6(3): 245-251.
19. Anim AK, Laar C, Osei J, Odonkor S, Enti-Brown S (2012) Trace metals quality of some herbal medicines sold in Accra, Ghana. Proceedings of the International Academy of Ecology and Environmental Sciences. 2(2): 111-117.

20. Nwachukwu RE, Janefrances NI, Jude IA, Fausta IOC, Simon UO (2018) Assessment of heavy metals content of some plant based medicines in parts of Southern Nigeria, West Africa. International Journal Pharmacy Science Resource 9(2): 775-783. 